\title{
Role of adjuvant therapy in T1-2N0 resected non-small cell lung cancer
}

\author{
Gavitt A. Woodard, MD, Andrew Li, MD, and Daniel J. Boffa, MD
}

Feature Editor's Introduction-The pace of treatment modifications for non-small cell lung cancer (NSCLC) in the advanced setting has exponentially increased over the past decade with refinements and new innovations in targeted therapy and the adoption of checkpoint inhibitors as monotherapy and in combination with chemotherapy. Innovations in improving survival in patients undergoing complete resection for early-stage or locally advanced NSCLC have been slower in comparison. Adjuvant chemotherapy for resected stage IA/B NSCLC has been evaluated in clinical trials dating back to the 1980s and 1990s with little proven survival benefit for stage $I A / B$ disease, with the exception for tumors $4 \mathrm{~cm}$ or greater based on the 7 th edition American Joint Committee on Cancer staging. The use of adjuvant targeted therapy in patients harboring actionable mutations (particularly epidermal growth factor receptor [EGFR]-mutated stage IB-IIIA NSCLC) has been explored with mixed results when comparing adjuvant erlotinib with placebo. ${ }^{1,2}$ Recently, adjuvant osimertinib was found to improve disease-free survival in completely resected stage IB-IIIA EGFR-mutated NSCLC with hazard ratios (0.17$0.20)$ that are rarely observed in clinical trials. The stage IB patients in this study appeared to derive some benefit (hazard ratio, 0.37) but only in the absence of standard adjuvant chemotherapy. ${ }^{3}$ In the end, this treatment will only benefit a small subset of patients with resected stage IB NSCLC because the prevalence of EGFR mutations in patients with early-stage lung cancer is approximately $10 \%$ to $15 \%$. In contrast, KRAS, the most frequent mutation $(\sim 30 \%)$ observed in resected NSCLC, has been targeted with sotorasib (directed at KRAS G12C-mutation) with early indications of a survival benefit in advanced NSCLC. ${ }^{4}$ This should prompt interest in studying such an inhibitor in the adjuvant setting after $R O$ resection of KRAS mutated NSCLC.

In this featured Expert Opinion, Woodard and colleagues have succinctly summarized the published data for adjuvant

\footnotetext{
From the Section of Thoracic Surgery, Department of Surgery, Yale School of Medicine, New Haven, Conn.

No external funding was required for this Expert Opinion. Funding was provided by the Yale Thoracic Oncology Program.

Received for publication Feb 3, 2021; revisions received May 20, 2021; accepted for publication May 30, 2021; available ahead of print July 10, 2021.

Address for reprints: Gavitt A. Woodard, MD, Section of Thoracic Surgery, Yale School of Medicine, 330 Cedar St, BB 205, New Haven, CT 06520 (E-mail: gavitt.woodard@yale.edu).

J Thorac Cardiovasc Surg 2022;163:1685-92

$0022-5223 / \$ 0.00$

Published by Elsevier Inc. on behalf of The American Association for Thoracic Surgery

https://doi.org/10.1016/j.jtcvs.2021.05.053
}

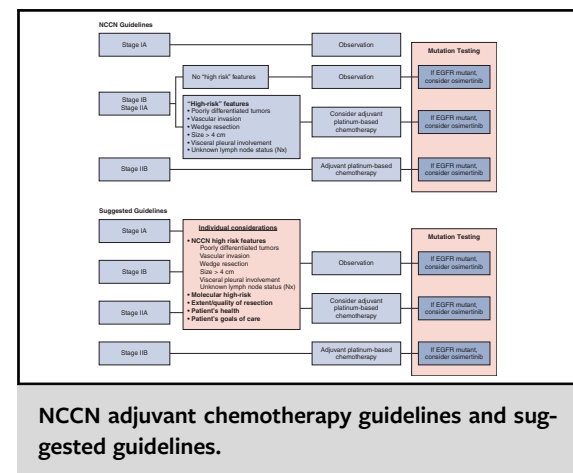

$$
\begin{aligned}
& \text { CENTRAL MESSAGE } \\
& \text { Use of platinum-based adjuvant } \\
& \text { therapy is recommended for } \\
& \text { select patients with stage IB and } \\
& \text { greater based on pathologic } \\
& \text { features. In EGFR mutant tumors, } \\
& \text { adjuvant osimertinib should also } \\
& \text { be considered. }
\end{aligned}
$$

This Invited Expert Opinion provides a perspective on the following paper: JAMA Oncol. 2020 Sep 17;6(11):1-10. https://doi.org/10.1001/jamaoncol. 2020.4232. Online ahead of print.

See Commentary on page 1693 .

chemotherapy and targeted therapy for resected T1-2NO NSCLC and introduced the concepts of prognostic and predictive biomarkers. The authors also acknowledge the plethora of ongoing investigations of adjuvant checkpoint inhibition for resected stage IB-IIIA NSCLC. Given the complex evolving landscape of treatment options for resectable NSCLC in both the adjuvant and neoadjuvant settings, it is important for thoracic surgeons to understand categories of treatment options (and their side effects) for their patients and the vocabulary associated with the integration of multi-modality treatments supported by these practicechanging clinical trials.

\section{Michael Lanuti, MD}

Over the past 2 decades, the role of adjuvant therapy after surgery in stage I non-small cell lung cancer (NSCLC) 
has evolved. The following overview is meant to outline the data and rationale behind current treatment recommendations in hopes of enhancing the shared decision-making process for oncology teams and their patients. This overview focuses on the role of adjuvant therapy after tumors have been completely resected, as opposed to patients with residual disease, for whom adjuvant therapy is more broadly recommended.

\section{THE ASSUMPTIONS OF ADJUVANT THERAPY IN EARLY-STAGE LUNG CANCER}

The rationale for administering systemic therapy to patients recovering from a complete $\mathrm{R} 0$ resection of an early-stage lung cancer is based on 2 key assumptions: (1) micrometastatic disease remains, and (2) additional therapy improves survival.

- Micrometastatic disease remains. Treating patients after surgery only makes sense if cancer remains after surgery. Among stage I adenocarcinomas, multiinstitution studies have observed a $26 \%$ recurrence rate after complete surgical resection. ${ }^{5}$ Therefore, it is clear that some patients retain micrometastatic disease after complete resection of early-stage lung cancer.

- Systemic therapy improves survival in patients with micrometastatic disease. Chemotherapy would only make sense after surgery if chemotherapy effectively kills the cells that are left behind. A growing body of randomized evidence has identified a survival advantage to giving adjuvant chemotherapy to certain subsets of completely resected lung cancer (Table 1).

\section{ADJUVANT CHEMOTHERAPY TRIALS IN EARLY- STAGE NON-SMALL CELL LUNG CANCER: THE DATA BEHIND THE GUIDELINES}

Clinical trials to study the impact of adjuvant chemotherapy in resected NSCLC began in the 1960s and showed conflicting results through the 1990s when the first metaanalysis was performed by the Non-Small Cell Lung Cancer Collaborative Group. This meta-analysis of 52 randomized clinical trials demonstrated a 5\% 5-year overall survival benefit to patients who underwent adjuvant chemotherapy after surgical resection. ${ }^{13}$ Although the survival advantage was not statistically significant $(P=.08)$, multiple subsequent studies with a renewed interest in adjuvant therapy followed (Table 1).

The Adjuvant Lung Project Italy randomized 1200 patients with stage I, II, and IIIA NSCLC to adjuvant mitomycin, vindesine, or cisplatin, or observation after surgical resection. This was a negative study showing no significant survival benefit to adjuvant chemotherapy among patients of any stage. ${ }^{6}$ Another early negative trial was the Big Lung Trial from Great Britain, which randomized 381 patients with stage I, II, and IIIA to different chemotherapy regimens versus observation and found no improvements in disease-free survival (DFS) or overall survival. ${ }^{10}$

TABLE 1. Summary of trials of adjuvant chemotherapy in early-stage non-small cell lung cancer

\begin{tabular}{|c|c|c|c|c|c|c|}
\hline Clinical trial & $\begin{array}{c}\text { Years } \\
\text { patients } \\
\text { enrolled }\end{array}$ & $\begin{array}{c}\text { No. of } \\
\text { patients }\end{array}$ & Chemotherapy regimen & $\begin{array}{l}\text { Stage } \\
\text { IA }\end{array}$ & Stage IB & Stage II \\
\hline $\begin{array}{l}\text { Adjuvant Lung Project } \\
\text { Italy (ALPI) }\end{array}$ & 1994-1999 & 482 & $\begin{array}{l}\text { Mitomycin, vindesine, or } \\
\text { cisplatin vs observation }\end{array}$ & $\begin{array}{l}\text { No } \\
\text { benefit }\end{array}$ & No benefit & No benefit \\
\hline $\begin{array}{l}\text { Adjuvant Navelbine } \\
\text { International Trialist } \\
\text { Association (ANITA) }{ }^{7}\end{array}$ & $1994-2000$ & 840 & Cisplatin/vinorelbine & - & No benefit & $\begin{array}{l}\text { Benefit } \\
\quad(\mathrm{HR}, 0.71)\end{array}$ \\
\hline JBR- $10^{8}$ & 1994-2001 & 482 & Cisplatin/vinorelbine & - & No benefit & $\begin{array}{l}\text { Benefit } \\
\quad(\mathrm{HR}, 0.59)\end{array}$ \\
\hline $\begin{array}{l}\text { International Adjuvant } \\
\text { Lung Trial (IALT) }\end{array}$ & $1995-2001$ & 1867 & Cisplatin/mitomycin & $\begin{array}{l}\text { No } \\
\text { benefit }\end{array}$ & No benefit & No benefit \\
\hline Big Lung Trial (BLT) ${ }^{10}$ & 1995-2001 & 381 & $\begin{array}{l}\text { Cisplatin, vindesine, } \\
\text { or vinorelbine }\end{array}$ & $\begin{array}{l}\text { No } \\
\text { benefit }\end{array}$ & No benefit & No benefit \\
\hline $\begin{array}{l}\text { Cancer and Leukemia } \\
\text { Group B (CALGB) } \\
9633^{11}\end{array}$ & $1996-2003$ & 344 & Carboplatin/paclitaxel & - & $\begin{array}{l}\text { No benefit overall; } \\
\text { benefit in tumors } \\
\geq 4 \mathrm{~cm} \text { (HR, 0.69) }\end{array}$ & - \\
\hline $\begin{array}{l}\text { Eastern Cooperative } \\
\text { Oncology Group } \\
(\mathrm{E} 1505)^{12}\end{array}$ & $2007-2013$ & 1501 & $\begin{array}{l}\text { Cisplatin-based chemo } \\
\text { vs cisplatin-based } \\
\text { chemotherapy plus } \\
\text { bevacizumab }\end{array}$ & - & $\begin{array}{l}\text { No benefit to adding } \\
\text { bevacizumab to } \\
\text { chemotherapy }\end{array}$ & $\begin{array}{l}\text { No benefit } \\
\text { to adding } \\
\text { bevacizumab to } \\
\text { chemotherapy }\end{array}$ \\
\hline
\end{tabular}

HR, Hazard ratio. 
The first large clinical trial to provide convincing evidence of the benefit of adjuvant chemotherapy in NSCLC after complete surgical resection was the International Adjuvant Lung Cancer Trial in 2003, although this benefit was not observed in the patient population with earlystage disease. After surgical resection, 1867 patients with stage I to III disease were randomized to cisplatin-based adjuvant chemotherapy or observation. Among all stages, patients treated with cisplatin-based adjuvant chemotherapy had improved 5 -year overall survival $(44.5 \%$ vs $40.4 \%, P<.03)$. However, with an analysis by stage, 681 randomized patients with stage I disease had a $34.5 \%$ mortality rate when treated with adjuvant chemotherapy and $35 \%$ when observed (hazard ratio [HR] for mortality not significant), and 452 patients with stage II had a $53.5 \%$ mortality rate when treated with adjuvant chemotherapy and $56.8 \%$ when observed (HR not significant), demonstrating no significant survival benefit to cisplatin-based adjuvant chemotherapy in the patient population with early-stage disease. ${ }^{9}$

JBR.10 was the North American Intergroup phase III clinical trial to study adjuvant vinorelbine/cisplatin versus observation in patients with stage IB and II NSCLC after complete surgical resection. Today, JBR.10 remains the clinical trial that demonstrates the greatest survival advantage to adjuvant chemotherapy. Overall recurrence rates were lower in the patients treated with adjuvant chemotherapy $36.0 \%$ than in patients in the observation group $49.6 \%(P=.003)$, and an absolute survival advantage was observed at 5 years in patients treated with adjuvant vinorelbine/cisplatin $69 \%$ versus those who were observed $54 \%(P=.03)$. However, for the patient population with early-stage disease, no statistical benefit was observed among those with stage IB specifically, although at 5 years, there did appear to be a survival advantage to adjuvant chemotherapy, and the authors cautioned that the negative findings among stage IB patients be interpreted with caution. JBR. 10 also stratified patients on the basis of the presence of a $R A S$ mutation. The presence of a $R A S$ mutation alone was not an independent predictor of survival; however, an interesting benefit to adjuvant chemotherapy was observed in patients with $R A S$ wild-type (HR, $0.69 ; 95 \%$ confidence interval [CI], 0.49-0.98; $P=.03$ ), and in patients with $R A S$ mutant, no survival advantage to adjuvant chemotherapy was observed (HR, 0.95; 95\% CI, 0.53-1.71; $P=.87$ ). ${ }^{8}$

The Adjuvant Navelbine International Trialist Association trial was a phase III trial of patients with stage IB, II, and IIIA NSCLC randomized to adjuvant vinorelbine/ cisplatin or observation with or without adjuvant radiation. Patients in the Adjuvant Navelbine International Trialist Association trial treated with adjuvant vinorelbine/cisplatin had an $8.6 \%$ improvement in overall survival at 5 years (HR, 0.80; 95\% CI, 0.66-0.96; $P=.017$ ). In concordance with other trials, the benefit of adjuvant chemotherapy was not seen in patients with stage IB disease (pT2N0 based on staging at the time), in whom 5-year survival was $62 \%$ with adjuvant chemotherapy and $64 \%$ with observation. Although a test of the interaction of tumor stage and chemotherapy on survival was not significant $(P=.07)$, the interaction between nodal status and chemotherapy did significantly affect survival $(P=.004)$; patients with N0 showed no survival benefit after adjuvant chemotherapy.

The use of size as a criterion for adjuvant chemotherapy is derived from data from the Cancer and Leukemia Group B (CALGB) 9633 trial. Preliminary results of the CALGB 9633 trial indicated improved survival in patients with stage IB NSCLC treated with adjuvant paclitaxel/carboplatin; patient accrual was stopped early because of this interim analysis. ${ }^{14}$ However, when mature analysis of the CALBG 9633 cohort was published in 2008, the median survival times were 95 months in the chemotherapy group and 78 months in the observation group (HR, $0.83 ; P=.125)$. Ironically, the study was underpowered to show statistical significance to this survival difference and ultimately showed no survival advantage in patients with stage IB overall. ${ }^{11}$ An unplanned subgroup analysis to look for patient populations who benefitted from adjuvant chemotherapy did show that there was a benefit to adjuvant paclitaxel/carboplatin therapy among the subset of patients with tumors greater than $4 \mathrm{~cm},{ }^{11}$ and this is the basis for size greater than $4 \mathrm{~cm}$ to be included as a high-risk criteria for adjuvant chemotherapy in the current National Cancer Center Network (NCCN) treatment guidelines.

The Lung Adjuvant Cisplatin Evaluation (LACE) collaborative group pooled data from 5 major studies to evaluate the benefit of adjuvant cisplatin on more than 4500 patients, including more than 1700 stage I patients. LACE found an $11 \%$ reduction in risk of death in patients treated with adjuvant chemotherapy overall and beneficial reduction in mortality among patients with stage II and III disease. However, the trend, although not significant, was seen in patients with stage IB disease, and no benefit was seen in stage IA patients. ${ }^{15}$

The only randomized clinical trial to show an adjuvant chemotherapy survival benefit in patients with stage I NSCLC was the Japan Lung Cancer Research Group study of approximately 1000 patients with stage I adenocarcinoma. Patients were randomized to oral uracil-tegafur for 2 years or observation after a complete surgical resection. In a subset of patients with $\mathrm{T} 2$ disease, this trial demonstrated a survival advantage of $85 \%$ in the uracil-tegafur treatment group versus $74 \%$ in the observation group. In patients with T1 disease and tumors greater than $2 \mathrm{~cm}$, there was also a significant survival advantage. ${ }^{16}$

The Eastern Cooperative Oncology Group E1505 trial examined the benefit of adding bevacizumab to platinumbased adjuvant chemotherapy regimens in completely resected stage IB to IIIA NSCLC. This phase 3, randomized, open-label trial of 1501 patients was ultimately negative 
and did not show an overall survival benefit with the addition of bevacizumab. ${ }^{12}$

\section{CURRENT ADJUVANT CHEMOTHERAPY GUIDELINES}

It is important to note that not all treatment guidelines from respected sources are in complete agreement across all oncologic scenarios. Because many recommendations are classified as Category 2A, they include consensus opinion and are expected to vary from organization to organization. The NCCN recommends adjuvant chemotherapy for completely resected stage I high-risk patients. Highrisk tumors may include tumors larger than $4 \mathrm{~cm}$, poorly differentiated tumors, vascular invasion, visceral pleural involvement, wedge resection, and unknown lymph node status (Nx) (Figure 1). Observation remains the NCCNrecommended approach for tumors less than $3 \mathrm{~cm}$, which under the eighth edition staging system is classified as stage IA. ${ }^{17}$ Although the NCCN currently recommends adjuvant chemotherapy for the stage I scenarios outlined, the American College of Chest Physician guidelines state that only stage II and greater tumors should receive adjuvant platinum-based chemotherapy. ${ }^{18}$

We recently examined more than 50,000 patients in the National Cancer Database to assess the survival benefit of adjuvant chemotherapy when NCCN high-risk pathologic features and size were considered simultaneously and found the following: ${ }^{19}$

- For tumors less than $3 \mathrm{~cm}$, adjuvant chemotherapy did not seem to improve outcomes (HR, 1.10; $P=.17$ ).

- For tumors 3 to $4 \mathrm{~cm}$, adjuvant chemotherapy only added benefit if the tumor had been removed by wedge resection (HR, $0.72 ; P=.004$ ).

- For tumors 4 to $5 \mathrm{~cm}$, adjuvant chemotherapy only benefited patients in the presence of at least 1 of the NCCN high-risk features (ie, if no high-risk features were present, chemotherapy did not help in this size category) (HR, $0.67 ; P=.02)$.

- For tumors greater than $5 \mathrm{~cm}$, adjuvant chemotherapy seemed to have a benefit, even in the absence of any high-risk features $(\mathrm{HR}, 0.75 ; P=.004)$.

\section{PERSONALIZED MEDICINE, TARGETED}

THERAPIES CURRENTLY AVAILABLE OR ON THE HORIZON

\section{Adjuvant Targeted Therapy}

The past decade has solidified the observation that the natural history of cancer can be altered through the systemic administration of novel therapies designed to target specific genetic changes within the cancer cells or therapies that disrupt an immune-escape mechanism. More recently, these trials have moved into the adjuvant setting for earlier-stage tumors (Table 2).
Based on the success of epidermal growth factor receptor (EGFR) tyrosine kinase inhibitors in advanced lung cancer, the RADIANT trial was designed to study the benefit of the tyrosine kinase inhibitor erlotinib in the adjuvant setting. A total of 973 patients with stage IB to IIIA were randomized in this international, double-blind, placebo-controlled study 2:1 to daily erlotinib or placebo for 2 years. Among patients with EGFR mutant tumors, DFS favored erlotinib (HR, $0.61, P=.039)$; however, this was not considered to be statistically significant because of between-arm imbalances and the hierarchical testing procedure. ${ }^{1}$

Recently, interim results from the ADAURA trial were published, showing dramatic improvements in DFS among patients with stage II and IIIA EGFR mutant tumors who were treated with 3 years of adjuvant osimertinib (HR, $0.17 ; 99 \% \mathrm{CI}, 0.11-0.26, P<.001) .{ }^{3}$ Differences in patients with stage IB EGFR mutant tumors were not significant, and there were no differences in overall survival in this interim analysis; however, the dramatic DFS results led to the approval of osimertinib for use in the adjuvant setting. It is worth noting that $60 \%$ of patients in the ADAURA trial were treated with adjuvant chemotherapy in addition to adjuvant osimertinib, and thus decisions about whom to treat with adjuvant platinum-based chemotherapy remain even when targeted therapies are used.

\section{Adjuvant Immunotherapy}

Immune checkpoint inhibitors remain investigational only among patients with early-stage disease, with many active ongoing clinical trials (Table 2). Given the benefit of adjuvant immunotherapy after chemotherapy and radiation in locally advanced disease, there is enthusiasm for their potential benefit in the adjuvant setting after surgical resection. However, it is unclear if immune checkpoint inhibitors will retain their benefit once the majority of a tumor burden has been removed. In this setting, we are reliant on the presence of residual micrometastatic disease to trigger an immune response. One large international phase III trial with mature results, the MAGRIT trial, was ultimately negative and failed to show a benefit to adding MAGE-A3 cancer immunotherapeutic to adjuvant chemotherapy regimens. The MAGRIT trial was a randomized, double-blind, placebo-controlled trial of MAGE-A3 cancer immunotherapeutic in patients with completely resected stage IB, II, and IIIA MAGE-A3positive NSCLC who did or did not receive adjuvant chemotherapy. There was no benefit in DFS compared with placebo (HR, 1.02; $P=.74) .{ }^{20}$

The Adjuvant Lung Cancer Enrichment Marker Identification and Sequencing Trial (ALCHEMIST) is an initiative to address the role of genomic testing and personalized therapies in the adjuvant treatment of NSCLC. The ANVIL arm is currently investigating adjuvant nivolumab among patients with stage IB to IIIA NSCLC after complete surgical 
NCCN Guidelines

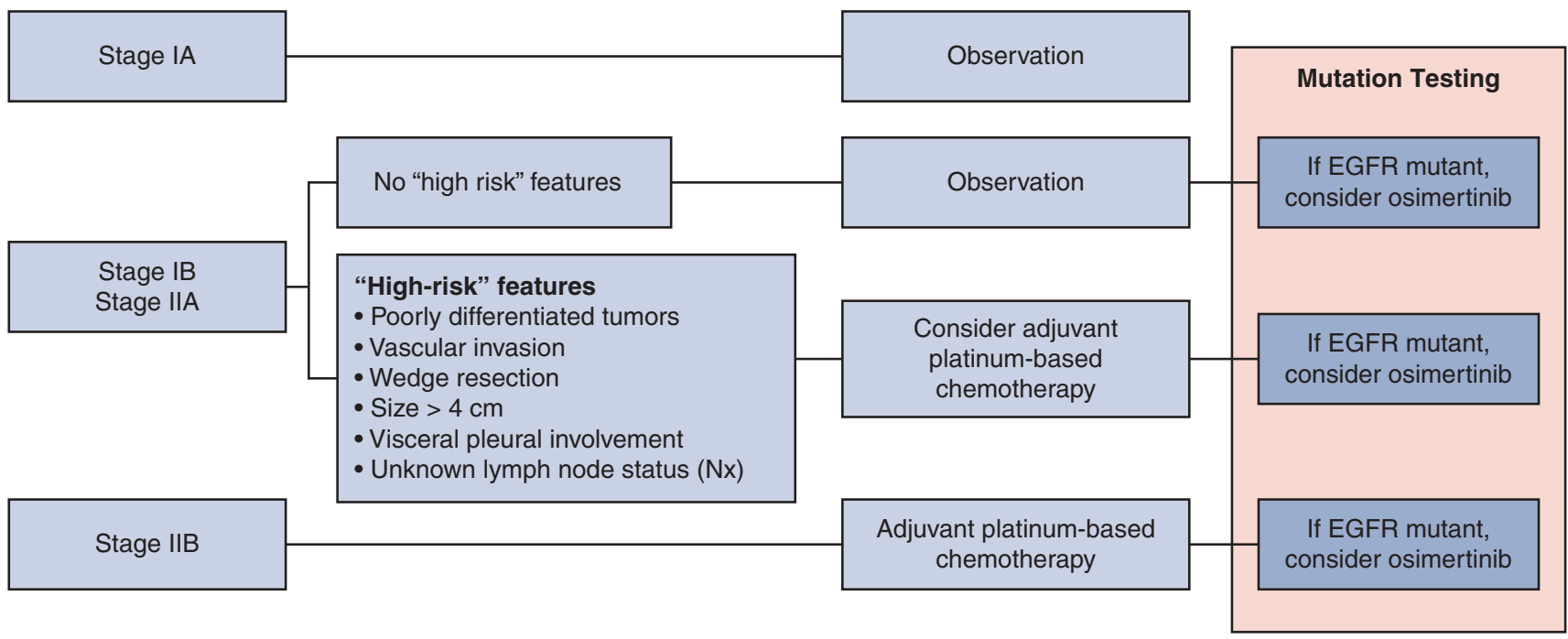

\section{Suggested Guidelines}

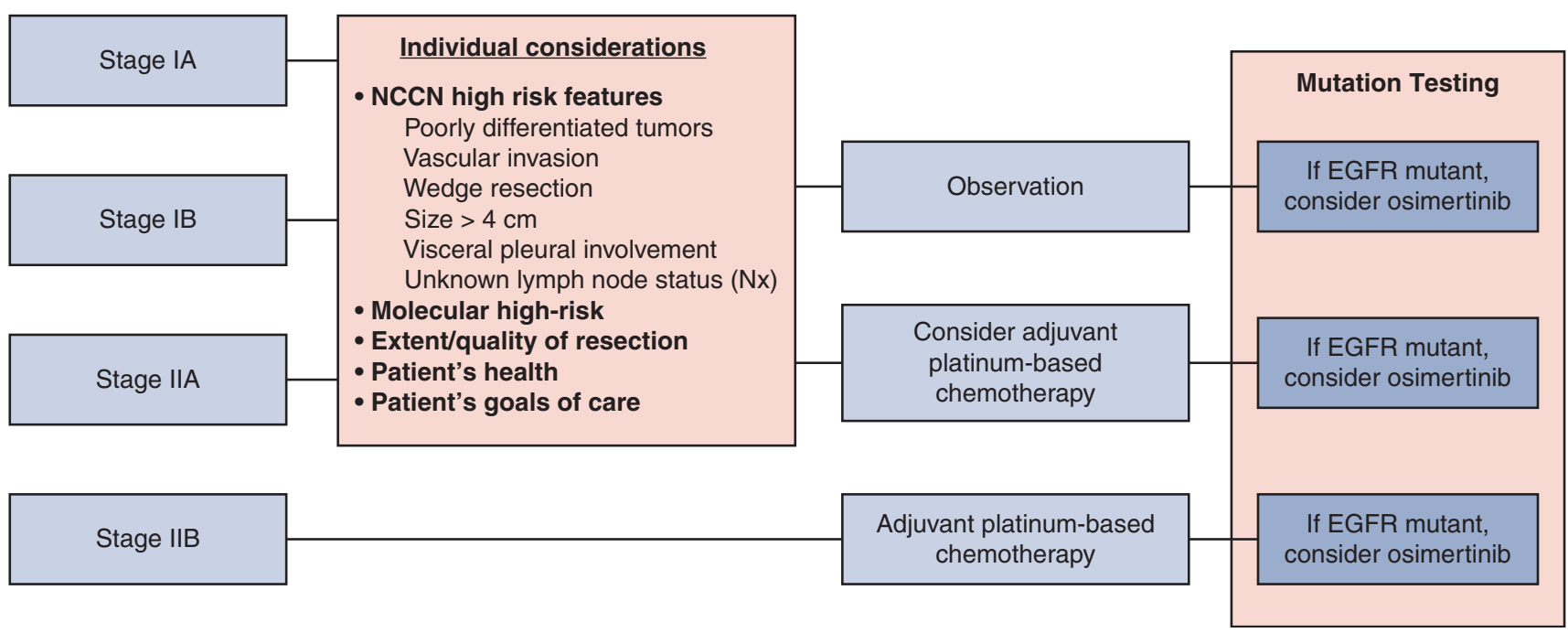

FIGURE 1. NCCN adjuvant chemotherapy guidelines and suggested guidelines. $E G F R$, Epidermal growth factor receptor; $N C C N$, National Cancer Center Network.

resection who cannot enroll in EGFR or ALK targeted trials. Many of the current clinical trials use adjuvant immunotherapy in addition to standard adjuvant chemotherapy (Table 2); therefore, similarly to targeted therapies, decisions about adjuvant cytotoxic chemotherapy still need to be made.

\section{Prognostic and Predictive Gene Signatures}

In the cancer biomarker world, there is an understanding that "prognostic" (likelihood to die) does not necessarily equate to "predictive" (likelihood systemic therapy kills cancer). However, there is some overlap in their clinical relevance. With this in mind, a number of studies have examined the role of biomarkers in the selection of patients for adjuvant therapy after complete resection of early-stage lung cancer.

\section{Tumor Protein Expression Markers}

Single gene/protein markers to predict a benefit from cisplatin-based adjuvant chemotherapy have been described. For example, tumors with excision repair cross-complementation group 1 protein expression on immunohistochemistry have been shown to have a worse response to cisplatin-based adjuvant chemotherapy and shorter DFS times than tumors without excision repair cross-complementation group 1 expression. ${ }^{21}$ Breast cancer 1 protein expression on immunohistochemistry also has been shown to predict worse DFS after adjuvant 
TABLE 2. Ongoing trials of targeted adjuvant therapy and immunotherapy

\begin{tabular}{|c|c|c|c|c|c|c|c|}
\hline \multicolumn{2}{|c|}{ Trial name } & \multirow{2}{*}{$\begin{array}{l}\text { Phase } \\
\text { III }\end{array}$} & \multirow{2}{*}{$\begin{array}{l}\text { Population } \\
\text { IB-IIIA }\end{array}$} & \multirow{2}{*}{$\frac{\text { Target }}{\text { EGFR }}$} & \multirow{2}{*}{$\begin{array}{r}\begin{array}{c}\text { Adjuvant } \\
\text { treatment }\end{array} \\
\text { Osimertinib } \times 3 \mathrm{y} \\
\pm \text { chemotherapy }\end{array}$} & \multirow{2}{*}{$\begin{array}{c}\begin{array}{c}\text { Enrollment } \\
\text { dates/status }\end{array} \\
\begin{array}{c}\text { Active, not } \\
\text { recruiting }\end{array}\end{array}$} & \multirow[b]{2}{*}{$\begin{array}{l}\text { Results } \\
\text { Improvement } \\
\text { in DFS in } \\
\text { stage II and } \\
\text { IIIA leading } \\
\text { to FDA } \\
\text { approval; } \\
\text { OS results } \\
\text { pending }\end{array}$} \\
\hline $\begin{array}{l}\text { ADAURA Trial } \\
\quad(\text { NCT02511106) }\end{array}$ & & & & & & & \\
\hline \multirow[t]{3}{*}{$\begin{array}{l}\text { ALCHEMIST } \\
\text { Trials }\end{array}$} & $\begin{array}{l}\text { EGFR } \\
\qquad(\text { NCT02193282) }\end{array}$ & III & IB-IIIA & EGFR & $\begin{array}{l}\text { Erlotinib } \times 2 \text { y after } \\
\text { complete resection } \\
\text { and standard } \\
\text { postoperative } \\
\text { therapy }\end{array}$ & Suspended & Suspended \\
\hline & $\begin{array}{l}\text { ALK } \\
\text { (NCT02201992) }\end{array}$ & III & IB-IIIA & ALK & $\begin{array}{l}\text { Crizotinib } \times 2 \text { y } \\
\text { after complete } \\
\text { resection } \pm \text { adjuvant } \\
\text { chemotherapy/ } \\
\text { radiation }\end{array}$ & Enrolling & Pending \\
\hline & $\begin{array}{l}\text { ANVIL } \\
\quad(\text { NCT02595944) }\end{array}$ & III & IB-IIIA & PD-L1 & $\begin{array}{l}\text { Nivolumab } \times 1 \text { y } \\
\text { after complete } \\
\text { resection }\end{array}$ & $\begin{array}{l}\text { Active, not } \\
\text { recruiting }\end{array}$ & Pending \\
\hline $\begin{array}{l}\text { IMpower-010 } \\
\text { (NCT02486718) }\end{array}$ & & III & IB-IIIA & PD-L1 & $\begin{array}{l}\text { Atezolizumab } \times 16 \\
\text { cycles after complete } \\
\text { resection and adjuvant } \\
\text { chemotherapy }\end{array}$ & $\begin{array}{l}\text { Active, not } \\
\text { Recruiting }\end{array}$ & Pending \\
\hline $\begin{array}{l}\text { BR31 } \\
\quad(\text { NCT02273375) }\end{array}$ & & III & IB-IIIA & PD-L1 & $\begin{array}{l}\text { Durvalumab } \times 1 \text { y } \\
\text { after complete } \\
\text { resection } \pm \text { adjuvant } \\
\text { chemotherapy }\end{array}$ & $\begin{array}{l}\text { Active, not } \\
\text { recruiting }\end{array}$ & Pending \\
\hline $\begin{array}{l}\text { MERMAID-1 } \\
\text { (NCT04385368) }\end{array}$ & & III & II-III & PD-L1 & $\begin{array}{l}\text { Durvalumab after } \\
\text { complete resection } \\
\text { and chemotherapy }\end{array}$ & Enrolling & Pending \\
\hline $\begin{array}{l}\text { PEARLS } \\
\qquad(\text { NCT02504372) }\end{array}$ & & III & IB-IIIA & PD-L1 & $\begin{array}{l}\text { Pembrolizumab } \times 1 \mathrm{y} \\
\text { after complete } \\
\text { resection } \pm \text { adjuvant } \\
\text { chemotherapy }\end{array}$ & $\begin{array}{l}\text { Active, not } \\
\text { recruiting }\end{array}$ & Pending \\
\hline NCT03053856 & & II & $\mathrm{N} 2+$ IIIA & PD-L1 & $\begin{array}{l}\text { Pembrolizumab } \times 2 \text { y } \\
\text { after complete } \\
\text { resection and } \\
\text { neoadjuvant } \\
\text { chemoradiotherapy }\end{array}$ & $\begin{array}{l}\text { Not yet } \\
\text { Recruiting }\end{array}$ & Pending \\
\hline
\end{tabular}

DFS, Disease-free survival; FDA, Food and Drug Administration; $O S$, overall survival.

chemotherapy. ${ }^{21}$ However, these studies of single biomarkers have not randomized patients to adjuvant chemotherapy versus observation; therefore, it has not been demonstrated that these tumor protein expression markers are predictive of poor response to adjuvant chemotherapy or are just prognostic markers of worse survival outcomes overall.

\section{Tumor Genetic Signatures}

Early-stage NSCLC remains an area ripe for the application of personalized medicine because these patients are either fully cured with a surgical resection alone or harbor micro-metastatic disease and at risk of recurrence. Identifying those patients at the greatest risk of harboring occult disease, and therefore most likely to benefit from adjuvant 
chemotherapy in this patient population, remains an area of active research interest.

In addition to single gene predictive markers, there have been a number of studies published on prognostic gene signatures, ${ }^{22}$ and most of them lack external validation. The only rigorously validated prognostic assay is a 14-gene expression profile (DetermaRx, OncoCyte Corp, Alameda, Calif). This assay has been internationally validated in more than 2000 patients $^{23}$ and among node-negative lesions smaller than $2 \mathrm{~cm},{ }^{24}$ and validated prospectively. ${ }^{25}$ It provides a prognostic risk assessment of mortality after surgical resection of a nonsquamous NSCLC. Its predictive accuracy in identifying patients with early-stage disease, even stage IA, who benefit from platinum-based adjuvant chemotherapy has been demonstrated prospectively. ${ }^{26}$ An international, prospective, randomized clinical trial is currently enrolling patients to further support these findings.

\section{IMPORTANT NOTES RELATED TO ADJUVANT THERAPY \\ Changes in the Staging System}

Changes in staging nomenclature should not be used to justify changes in the adjuvant therapy approach. Because the stage classification system is continually updated, changing from the eighth to ninth to tenth editions of the AJCC staging manual, patients may appear to change their staging designation overnight. For example, a patient with a 4.1-cm T2aN0M0 (stage IB) tumor under the seventh edition is upstaged to a $4.1-\mathrm{cm}$ T2bNOM0 (stage IIA) tumor using the eighth edition. If a patient's stage designation changes from one for which you would not administer chemotherapy to one for which you would, this change in stage designation should not be used to justify a change in management. ${ }^{27}$

\section{Try to Understand the "Driver of the Patient's Demise"}

For many patients with lung cancer, there are multiple competing risks to their survival relating to their recently resected cancer, including risk recurrence, other cancers, and health concerns unrelated to cancer. We have recently shown that the benefit of a lobectomy over a wedge resection diminishes considerably among patients with shorter life expectancy due to age and comorbidities. ${ }^{28}$ The decision for adjuvant chemotherapy may be heavily influenced by their potential to survive long enough to derive a benefit from additional therapy. In addition, it is critical to understand the goals of care for each individual patient and not assume that all patients who might obtain a small theoretical survival benefit are willing to undergo adjuvant treatments. In our experience, many older patients and those with poor functional status favor observation if the anticipated benefit from adjuvant chemotherapy is small.

\section{CONCLUSIONS}

The appropriate selection of patients with early-stage NSCLC for adjuvant chemotherapy after complete surgical resection remains a challenge with conflicting trial data. Currently, there are no data to support the use of adjuvant chemotherapy among unselected patients with stage IA. Patients with stage IB and IIA with high-risk pathologic features are likely to obtain a benefit from adjuvant chemotherapy, but the decision should follow a thoughtful discussion with consideration for the individual patient's preferences. More sophisticated guidelines for what constitutes high-risk pathology, perhaps based on tumor genetics or molecular markers, are needed. The role of targeted therapies and immunotherapy in the adjuvant setting remains investigational and would be to supplement and not to replace adjuvant platinum-based chemotherapy.

\section{Conflict of Interest Statement}

The authors reported no conflicts of interest.

The Journal policy requires editors and reviewers to disclose conflicts of interest and to decline handling or reviewing manuscripts for which they may have a conflict of interest. The editors and reviewers of this article have no conflicts of interest.

\section{References}

1. Kelly K, Altorki NK, Eberhardt WE, O'Brien ME, Spigel DR, Crino L, et al. Adjuvant erlotinib versus placebo in patients with stage IB-IIIA non-small-cell lung cancer (RADIANT): a randomized, double blind, phase III trial. J Clin Oncol. 2015;33:4007-14.

2. Pennell NA, Neal JW, Chaft JE, Azzoli CG, Jänne PA, Govindan R, et al. SELECT: a phase II trial of adjuvant erlotinib in patients with resected epidermal growth factor receptor-mutant non-small-cell lung cancer. J Clin Oncol. 2019;37: 97-104.

3. Wu YL, Tsuboi M, He J, John T, Grohe C, Majem M, et al. Osimertinib in resected EGFR-mutated non-small-cell lung cancer. $N$ Engl J Med. 2020;383: 1711-23.

4. Skoulidis F, Li BT, Dy GK, Price TJ, Falchook GS, Wolf J, et al. Sotorasib for lung cancers with KRAS p.G12C mutation. N Engl J Med. 2021;384:2371-81.

5. Guerrera F, Lococo F, Evangelista A, Rena O, Ampollini L, Vannucci J, et al. Risk of recurrence in stage I adenocarcinoma of the lung: a multi-institutional study on synergism between type of surgery and type of nodal staging. J Thorac Dis. 2019;11:564-72

6. Scagliotti GV, Fossati R, Torri V, Crinò L, Giaccone G, Silvano G, et al. Randomized study of adjuvant chemotherapy for completely resected stage I, II, or IIIA non-small-cell lung cancer. J Natl Cancer Inst. 2003;95:1453-61.

7. Douillard JY, Rosell R, De Lena M, Carpagnano F, Ramlau R, GonzálesLarriba JL, et al. Adjuvant vinorelbine plus cisplatin versus observation in patients with completely resected stage IB-IIIA non-small-cell lung cancer (Adjuvant Navelbine International Trialist Association [ANITA]): a randomised controlled trial. Lancet Oncol. 2006;7:719-27.

8. Winton T, Livingston R, Johnson D, Rigas J, Johnston M, Butts C, et al. Vinorelbine plus cisplatin vs observation in resected non-small-cell lung cancer. N Engl J Med. 2005;352:2589-97. 
9. Arriagada R, Bergman B, Dunant A, Le Chevalier T, Pignon JP, Vansteenkiste J. Cisplatin-based adjuvant chemotherapy in patients with completely resected non-small-cell lung cancer. N Engl J Med. 2004;350:351-60.

10. Waller D, Peake MD, Stephens RJ, Gower NH, Milroy R, Parmar MK, et al. Chemotherapy for patients with non-small cell lung cancer: the surgical setting of the Big Lung Trial. Eur J Cardiothorac Surg. 2004;26:173-82.

11. Strauss GM, Herndon JE II, Maddaus MA, Johnstone DW, Johnson EA, Harpole DH, et al. Adjuvant paclitaxel plus carboplatin compared with observation in stage IB non-small-cell lung cancer: CALGB 9633 with the Cancer and Leukemia Group B, Radiation Therapy Oncology Group, and North Central Cancer Treatment Group study Groups. J Clin Oncol. 2008;26:5043-51.

12. Wakelee HA, Dahlberg SE, Keller SM, Tester WJ, Gandara DR, Graziano SL, et al. Adjuvant chemotherapy with or without bevacizumab in patients with resected non-small-cell lung cancer (E1505): an open-label, multicentre, randomised, phase 3 trial. Lancet Oncol. 2017;18:1610-23.

13. Non-small Cell Lung Cancer Collaborative Group. Chemotherapy in non-small cell lung cancer: a meta-analysis using updated data on individual patients from 52 randomised clinical trials. BMJ. 1995;311:899-909.

14. Strauss GM, Herndon J, Maddaus MA, Johnstone DW, Johnson EA, Watson DM, et al. Randomized clinical trial of adjuvant chemotherapy with paclitaxel and carboplatin following resection in stage IB non-small cell lung cancer (NSCLC): report of Cancer and Leukemia Group B (CALGB) Protocol 9633. J Clin Oncol. 2004;22(14_suppl):7019.

15. Pignon JP, Tribodet H, Scagliotti GV, Douillard JY, Shepherd FA, Stephens RJ, et al. Lung adjuvant cisplatin evaluation: a pooled analysis by the LACE Collaborative Group. J Clin Oncol. 2008;26:3552-9.

16. Kato H, Ichinose Y, Ohta M, Hata E, Tsubota N, Tada H, et al. A randomized trial of adjuvant chemotherapy with uracil-tegafur for adenocarcinoma of the lung. $N$ Engl J Med. 2004;350:1713-21.

17. NCCN. NCCN non-small cell lung cancer clinical practice guidelines. Available at: http://www.nccn.org/professionals/physician_gls/pdf/nscl.pdf. Accessed November 15, 2020.

18. Detterbeck FC, Lewis SZ, Diekemper R, Addrizzo-Harris D, Alberts WM. Executive Summary: diagnosis and management of lung cancer, 3rd ed: American College of Chest Physicians evidence-based clinical practice guidelines. Chest. 2013;143(5 Suppl):7s-37s.

19. Pathak R, Goldberg SB, Canavan M, Herrin J, Hoag JR, Salazar MC, et al. Association of survival with adjuvant chemotherapy among patients with early-stage non-small cell lung cancer with vs without high-risk clinicopathologic features. JAMA Oncol. 2020;6:1-10.
20. Vansteenkiste JF, Cho BC, Vanakesa T, De Pas T, Zielinski M, Kim MS, et al. Efficacy of the MAGE-A3 cancer immunotherapeutic as adjuvant therapy in patients with resected MAGE-A3-positive non-small-cell lung cancer (MAGRIT): a randomised, double-blind, placebo-controlled, phase 3 trial. Lancet Oncol. 2016;17:822-35.

21. Huang ZL, Cao X, Luo RZ, Chen YF, Zhu LC, Wen Z. Analysis of ERCC1, BRCA1, RRM1 and TUBB3 as predictors of prognosis in patients with nonsmall cell lung cancer who received cisplatin-based adjuvant chemotherapy: a prospective study. Oncol Lett. 2016;11:299-305.

22. Chen HY, Yu SL, Chen CH, Chang GC, Chen CY, Yuan A, et al. A five-gene signature and clinical outcome in non-small-cell lung cancer. $N$ Engl J Med. 2007;356:11-20.

23. Kratz JR, He J, Van Den Eeden SK, Zhu ZH, Gao W, Pham PT, et al. A practical molecular assay to predict survival in resected non-squamous, non-small-cell lung cancer: development and international validation studies. Lancet. 2012; 379:823-32.

24. Kratz JR, Van den Eeden SK, He J, Jablons DM, Mann MJ. A prognostic assay to identify patients at high risk of mortality despite small, node-negative lung tumors. JAMA. 2012;308:1629-31.

25. Woodard GA, Wang SX, Kratz JR, Zoon-Besselink CT, Chiang CY, Gubens MA, et al. Adjuvant chemotherapy guided by molecular profiling and improved outcomes in early stage, non-small-cell lung cancer. Clin Lung Cancer. 2018;19: 58-64.

26. Woodard GA, Kratz JR, Haro G, Gubens MA, Blakely CM, Jones KD, et al. Molecular risk stratification is independent of EGFR mutation status in identifying early-stage NSCLC patients at risk for recurrence and likely to benefit from adjuvant chemotherapy. Paper presented at: IASLC North America Conference on Lung Cancer, October 16, 2020; Virtual Presentation.

27. Boffa DJ, Detterbeck FC, Smith EJ, Rami-Porta R, Crowley J, Zelterman D, et al. Should the 7 th edition of the lung cancer stage classification system change treatment algorithms in non-small cell lung cancer? J Thorac Oncol. 2010;5:1779-83.

28. Salazar MC, Canavan M, Walters SL, Chilakamarry S, Ermer T, Blasberg JD, et al. The survival advantage of lobectomy over wedge resection lessens, as health-related life expectancy decreases. J Thorac Oncol Clin Res Rep. 2021 [In press].

Key Words: adjuvant therapy, early-stage NSCLC, NCCN guidelines, prognostic markers, treatment recommendations 